\title{
Thioxoethenylidene (CCS) as a Bridging Ligand
}

\author{
Lorraine M. Caldwell, Anthony F. Hill,* Robert Stranger, Richard N. L. Terrett, Kassetra M. von Nessi, \\ Jas S. Ward and Anthony C. Willis
}

Research School of Chemistry, The Australian National University, Canberra, ACT 0200, Australia.

Supporting Information

\begin{abstract}
The reaction of $\left[\mathrm{Mo}(\equiv \mathrm{CBr})(\mathrm{CO})_{2}\left(\mathrm{Tp}^{*}\right)\right]\left(\mathrm{Tp}^{*}=\right.$ hydrotris $(3,5$-dimethylpyrazol1-yl)borate) with $\left[\mathrm{Fe}_{2}(\mu-\mathrm{SLi})_{2}(\mathrm{CO})_{6}\right]$ affords, inter alia, the unsymmetrical binuclear thioxoethenylidene complex $\left[\mathrm{Mo}_{2}\left(\mu: \sigma-\mathrm{C} ; \eta^{2}-C^{\prime} S-\mathrm{CCS}\right)(\mathrm{CO})_{4}(\mathrm{Tp})_{2}\right]$ which may be more directly obtained from $\left[\mathrm{Mo}(\equiv \mathrm{CBr})(\mathrm{CO})_{2}\left(\mathrm{Tp}^{*}\right)\right]$ and $\mathrm{Li}_{2} \mathrm{~S}$. The reaction presumably proceeds via the intermediacy of the bis(alkylidynyl)thioether complex $\mathrm{S}\left\{\mathrm{C} \equiv \mathrm{Mo}(\mathrm{CO})_{2}\left(\mathrm{Tp}^{*}\right)\right\}_{2}$ which was, however, not directly observed but explored computationally and found to lie $78.6 \mathrm{~kJ} \mathrm{~mol}^{-1}$ higher in energy than the final thioxoethenylidene product. Computational interrogation of the molecules $\left[\mathrm{M}_{2}\left(\mu-\mathrm{C}_{2} \mathrm{~S}\right)(\mathrm{CO})_{2}\left(\mathrm{Tp}^{*}\right)_{2}\right](\mathrm{M}=\mathrm{Mo}, \mathrm{W}, \mathrm{Re}, \mathrm{Os})$ reveals three plausible coordination modes for a thioxoethenylidene bridge which involve a progressive strengthening of the $\mathrm{C}-\mathrm{C}$ bond and weakening of the $\mathrm{M}-\mathrm{C}$ and $\mathrm{M}-\mathrm{S}$ bonds, as might be expected from simple effective atomic number considerations.
\end{abstract}

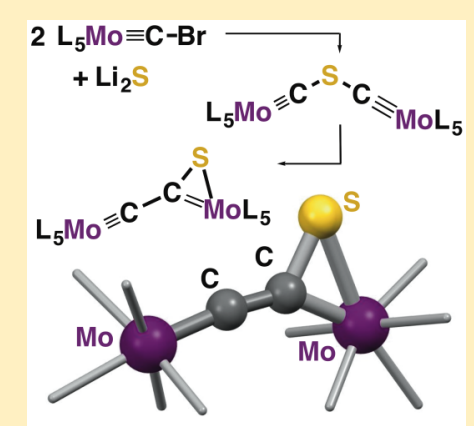

\section{INTRODUCTION}

Wilkinson's discovery of the first coordination complex of carbon monosulfide, $\left[\mathrm{RhCl}(\mathrm{CS})\left(\mathrm{PPh}_{3}\right)_{2}\right],{ }^{1,2}$ pre-dated the observation of this diatomic in inter-stellar space, ${ }^{3}$ where high dilution ensures it longevity. Back on earth, carbon disulfide exposed to electric discharge allows the generation and matrix entrapment of $\mathrm{CS}$ at $-190{ }^{\circ} \mathrm{C}$. ${ }^{4}$ Its tendency to polymerise explosively above such temperatures, however, somewhat curtails its synthetic utility, a feature that has inspired the study of its more easily tamed coordination complexes. ${ }^{2}$ Somewhat later, Saito also observed thioxoethenylidene, CCS, in inter-stellar clouds ${ }^{5}$ and similarly, irradiation $(248 \mathrm{~nm})$ of propadienedithione $\left(\mathrm{SC}_{3} \mathrm{~S}\right)$ entrapped in an argon matrix $(10 \mathrm{~K})$ has allowed the terrestrial observation of transient, triplet CCS $\left(v_{1}=1666.6 \mathrm{~cm}^{-1}\right){ }^{6}$ In contrast to the rich organometallic chemistry of carbon monosulfide, no complex of coordinated $\mathrm{C}_{2} \mathrm{~S}$ has been reported, though the ketenylidene ligand ( $\mathrm{CCO}$ ) has often been observed in cluster chemistry $^{7}$ and a terminal mononuclear ketenylidene ligand has been implicated in the cleavage of carbon suboxide by $\left[\mathrm{WCl}_{2}\left(\mathrm{PMePh}_{2}\right)_{4}\right] .{ }^{8}$ Thioketenyl and selenoketenyl complexes $\mathrm{L}_{\mathrm{n}} \mathrm{M}\left(\eta^{2}-C, C^{\prime}\right.$-ACCR $)(\mathrm{M}=\mathrm{Mo}, \mathrm{W} ; \mathrm{A}=\mathrm{S}, \mathrm{Se})$ have, however, been reported to arise from the reactions of ketenyl complexes with Lawesson's and Woollins' reagents, respectively.

Herein we report both serendipitous and strategic syntheses of the first example of a complex of thioxoethenylidene, viz. $\left[\mathrm{Mo}_{2}\left(\mu: \sigma-\mathrm{C} ; \eta^{2}-C^{\prime} S-\mathrm{CCS}\right)(\mathrm{CO})_{4}\left(\mathrm{Tp}^{*}\right)\right] \quad\left(\mathrm{Tp}^{*}=\operatorname{hydrotris}(3,5-\right.$ dimethylpyrazol-1-yl)borate) and an exploration of its bonding as a function of the number of available metal valence electrons.

\section{RESULTS AND DISCUSSION}

We have previously reported the synthesis of polymetallic assemblies bridged by isoselenocarbonyl ligands. ${ }^{10}$ These arise from either the insertion of zerovalent platinum into the $\mathrm{C}-\mathrm{Se}$ bond of alkynylselenolatocarbynes ${ }^{10 \mathrm{a}}$ or reactions of the selenocarbonylate $\left[\mathrm{Mo}(\mathrm{CSe})(\mathrm{CO})_{2}\left(\mathrm{Tp}^{*}\right)\right]^{-}$anion $^{11}$ with metal halide complexes. ${ }^{10 \mathrm{~b}, \mathrm{c}}$ This latter approach builds upon the early demonstration by Angelici that thiocarbonyl ligands are more prone to attack at sulfur by electrophiles (including transition metal centres) than are carbonyl ligands. ${ }^{12}$ Notably, however, Angelici's studies of the reactions of $\left[\mathrm{W}(\mathrm{CS})(\mathrm{CO})_{2}(\mathrm{Tp})\right]^{-}(\mathrm{Tp}=$ hydrotris(pyrazol-1yl)borate) with metal electrophiles afforded bimetallic complexes in which the thiocarbonyl adopted either a semi-bridging (2-electron) ${ }^{13}$ or $\sigma-\pi$ (4-electron) bridging ${ }^{14}$ mode, rather than an isothiocarbonyl linkage.

The reactions of $\left[\mathrm{Fe}_{2}\left(\mu-\mathrm{S}_{2}\right)(\mathrm{CO})_{6}\right]^{15}$ with alkynyl nucleophiles result in alkynylthiolato-bridged diiron complexes, subsequent electrophilic quenching of which may occur at the $\mu$-sulfido or either carbon atom of the alkynylthiolato bridge (Scheme 1). ${ }^{16}$

Scheme 1. Generation and Electrophilic Quenching of a Binuclear Alkynylthiolato Complex. ${ }^{16}$

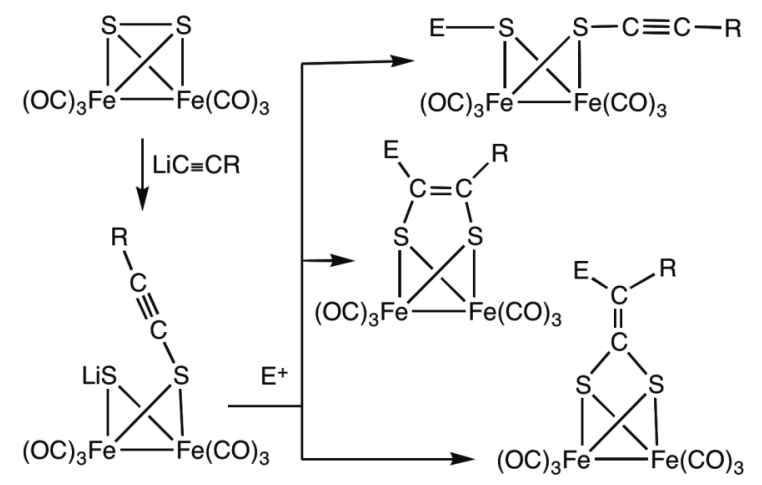


In search of alternative methods of assembling isothiocarbonyl linkages, we therefore considered whether the nucleophilic carbido complex $\left[\mathrm{Mo}(\mathrm{CLi})(\mathrm{CO})_{2}\left(\mathrm{Tp}^{*}\right)\right](\mathbf{1})^{11}$ might similarly cleave the disulfido bridge of $\left[\mathrm{Fe}_{2}\left(\mu-\mathrm{S}_{2}\right)(\mathrm{CO})_{6}\right]$ to generate an intermediate (Li[A], Scheme 1) akin to that in Scheme 1. Although this type of bridging mode is unprecedented for CS, we have recently observed it for $\mathrm{CSe}$ in the tetranuclear complex $\left[\mathrm{Mo}_{2} \mathrm{Rh}_{2}(\mu-\mathrm{CSe})_{2}(\mathrm{CO})_{4}\left(\eta^{4}-\right.\right.$ $\left.\operatorname{cod})_{2}\left(\mathrm{Tp}^{*}\right)_{2}\right](\operatorname{cod}=1,5$-cyclo-octadiene $){ }^{10 \mathrm{f}}$

We therefore anticipated that trapping the intermediate with an equivalent of $\left[\mathrm{Mo}(\mathrm{CBr})(\mathrm{CO})_{2}\left(\mathrm{Tp}^{*}\right)\right](2)$ might afford an analogous complex $\quad\left[\mathrm{Mo}_{2} \mathrm{Fe}_{2}\left(\mu_{3}-\mathrm{CS}\right)_{2}(\mathrm{CO})_{10}\left(\mathrm{Tp}^{*}\right)_{2}\right] \quad(\mathbf{B}, \quad$ Scheme 2). Alternatively, and more conveniently, we considered whether the same species $[\mathbf{A}]^{-}$and $\mathbf{B}$ might be accessible via the direct reaction of $\left[\mathrm{Fe}_{2}(\mu-\mathrm{SLi})_{2}(\mathrm{CO})_{6}\right]$ with one and two equivalents, respectively of 2. A computational exploration of the viability and optimal geometries of $[\mathbf{A}]^{-}$and $\mathbf{B}$ is presented in the Supporting Information, lending weight to the analogy with Seyferth's alkynylthiolato chemistry. In practice, however, sequential treatment of 2 with $\left[\mathrm{Fe}_{2}(\mu-\mathrm{SLi})_{2}(\mathrm{CO})_{6}\right]$ afforded a daunting plethora of products, only one of which, obtained in low yield, has so far yielded to isolation and identification. The green complex obtained after extensive chromatographic purification was identified on the basis of spectroscopic, mass spectrometric and crystallographic data as the (iron-free) unsymmetrical CCS-bridged bimetallic complex $\left[\mathrm{Mo}_{2}\left(\mu: \sigma-C ; \eta^{2}-C^{\prime} S-\mathrm{CCS}\right)(\mathrm{CO})_{4}\left(\mathrm{Tp}^{*}\right)\right](3$, Scheme 2$)$.

\section{Scheme 2. Alternative Syntheses of a Thioxoethenylidene} Complex.

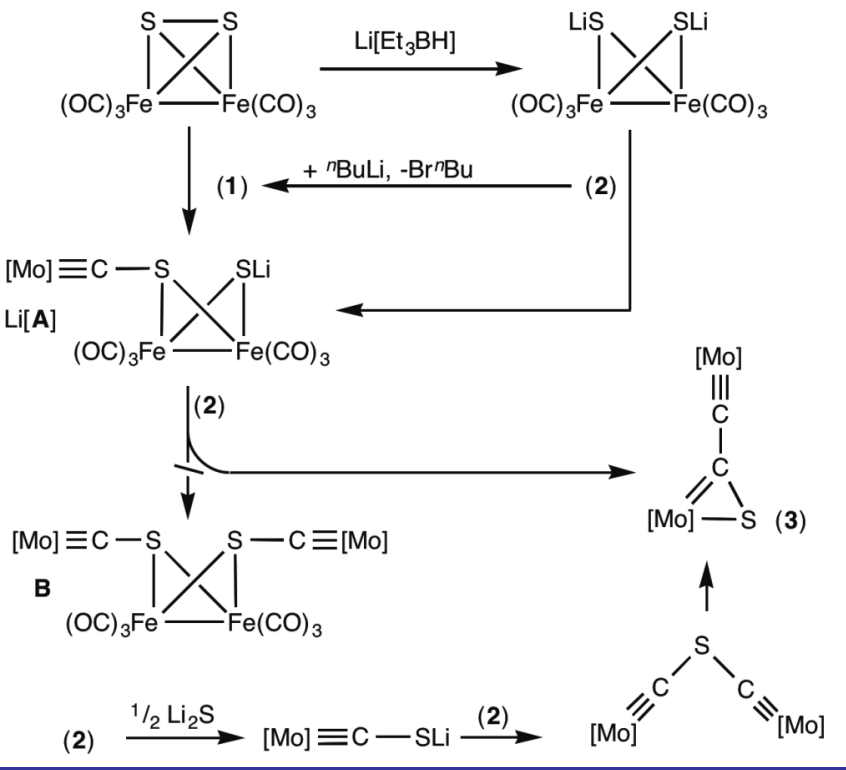

Once recognised as such, a more expedient and strategic synthesis became immediately obvious involving the simple, albeit slow, reaction of 2 with half an equivalent of $\mathrm{Li}_{2} \mathrm{~S}$ (from $\mathrm{Li}\left[\mathrm{Et}_{3} \mathrm{BH}\right]$ and sulfur). The reaction of $\left[\mathrm{Mo}(\equiv \mathrm{CCl})(\mathrm{CO})_{2}\left(\mathrm{Tp}^{*}\right)\right](4)$ with $\mathrm{Li}_{2} \mathrm{~S}$ has been reported to afford (after cation metathesis) the salt $\left[\mathrm{Et}_{4} \mathrm{~N}\right]\left[\mathrm{Mo}(\mathrm{CS})(\mathrm{CO})_{2}\left(\mathrm{Tp}^{*}\right)\right]$ which was characterised on the basis of its infrared spectrum $\left(v_{\mathrm{CO}}: 1886,1794, v_{\mathrm{CS}}: 1139 \mathrm{~cm}^{-1}\right){ }^{11 \mathrm{a}}$ Alternatively, treating 1 with elemental sulfur directly affords the lithium analogue $\mathrm{Li}\left[\mathrm{Mo}(\mathrm{CS})(\mathrm{CO})_{2}\left(\mathrm{Tp}^{*}\right)\right]{ }^{11 \mathrm{~b}}$ In our experience, the bromocarbyne complex $\mathbf{2}$ is somewhat more reactive towards nucleophilic substitution than $\mathbf{4}$ which perhaps accounts for the reaction of $\mathrm{Li}\left[\mathrm{Mo}(\mathrm{CS})(\mathrm{CO})_{2}\left(\mathrm{Tp}^{*}\right)\right]$ with a further equivalent of $\mathbf{2}$ to afford 3 (Scheme 2).

The complex 3 may be thought of as a hybrid of an alkylidyne complex and a thioacyl complex, with each component having precedent. The field of carbyne complexes ligated by poly(pyrazolyl)borate ligands is diverse and has been reviewed. ${ }^{17}$ Mononuclear chalcoacyl complexes of the group 6 metals $^{18}$ are more scarce, being limited to those arising from the reactions of alkylidyne complexes with either propylene sulfide ${ }^{18 \mathrm{a}}$ or mesityl isoselenocyanate. $^{18 \mathrm{c}}$ A small number of thiocarboxamide, thioaryloxycarbonyl and dithioaryloxycarbonyl derivatives are however known, in which the organyl substituent is replaced by amino, alkoxy or thiolato substituents. ${ }^{19}$ Binuclear chalcoacyl complexes, however all adopt a dimetallachalcotetrahedrane geometry in which the $\mathrm{CE}(\mathrm{E}=\mathrm{S}, \mathrm{Se}, \mathrm{Te})$ group transversely bridges a metal-metal bond (Chart 1$),{ }^{20}$ with the exception of $[\mathrm{MRu}(\mu$ $\left.\left.\mathrm{SCC}_{6} \mathrm{H}_{4} \mathrm{Me}-4\right)(\mathrm{CO})_{4}\left(\eta^{5}-\mathrm{C}_{2} \mathrm{~B}_{9} \mathrm{H}_{9} \mathrm{Me}_{2}\right)(\mathrm{Tp})\right] \quad(\mathrm{Chart} \quad 1 \mathrm{e} ; \mathrm{Tp}=$ hydrotris(pyrazol-1-yl)borate). ${ }^{21}$

Chart 1. Coordination Modes for Chalcoacyl and Related Ligands. (a) Monohapto; (b) Dihapto; (c) Parallel Bridging; (d) Transverse Bridging; (e) $\sigma-\pi$ Bridging.<smiles>[R]C([R])=[V]</smiles><smiles>FC1=[M]C1</smiles>

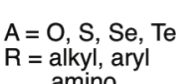

$=$ alkyl, ary alkoxy, thiolato (c) $R$<smiles>[Y]1=C[I-]=1</smiles><smiles>[R]C1=C[Y14]=C1</smiles>

(d)

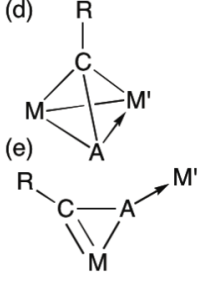

The spectroscopic data for $\mathbf{3}$, whilst indicating a binuclear complex of low symetry, did not allow for unequivocal identification, not least because the small range of ${ }^{13} \mathrm{C} N \mathrm{NMR}$ data reported for thioacyl groups $^{18}$ overlaps somewhat with the wide range observed for alkyidyne ligands (vide infra, Table $1^{18,19,22-28}$ ). ${ }^{17}$ The formulation was however confirmed by a crystallographic analysis, the results of which are summarised in Figure 1. Although, as noted, group 6 thioacyl complexes have been reported previously, ${ }^{18}$ this was without recourse to structural characterisation. Accordingly, the previously described complex $\left[\mathrm{Mo}\left(\eta^{2}-\mathrm{SCC}_{4} \mathrm{H}_{3} \mathrm{~S}-2\right)(\mathrm{CO})_{2}(\mathrm{Tp})\right] \quad(\mathbf{5})^{18 \mathrm{a}}$ was characterised crystallographically to provide a benchmark for more conventional thioacyl metrics (Figure 2). Metrical parameters resulting from geometrical optimisation at the $\mathrm{BP} / \mathrm{TZP}$ level of theory (vide infra) are collected with those derived experimentally for $\mathbf{3}$ and 5 in Table 2, from which it is clear that the coordination of the CCS bridge to $\mathrm{Mol}$ is indeed best described as a thioacyl/molybdathiirene composite. Thus the Mo1-C1 bond length of 2.018(3) $\AA$, points towards the retention of considerable multiple bond (metallathiirene) character, being shorter than typically observed for molybdenum bound to monohapto $s p^{2}-\mathrm{C}$ vinyl, acyl or N-heterocyclic carbene ligands $(2.15-2.30 \AA)$ and falling between the ranges typical of Fischer-type ( $>2.0 \AA)$ and Schrock-type carbene $(<2.0 \AA)$ ligands. ${ }^{29}$ The coordination to Mo2 in contrast is entirely consistent with the presence of an essentially linear ${ }^{30}$ carbyne ligand $(\mathrm{Mo}-\mathrm{C} 2-\mathrm{C} 1=$ $\left.169.9(2)^{\circ}, \mathrm{Mo} 2-\mathrm{C} 2=1.842(3) \AA\right)$, for which the compounds $\left[\mathrm{Mo}_{2}(\mu-\right.$ $\left.\left.\mathrm{C}_{2}\right)(\mathrm{CO})_{4}\left(\mathrm{Tp}^{*}\right)_{2}\right] \quad(6$ : $\mathrm{Mo}-\mathrm{C} \quad=1.857(3) \AA) \quad$ and $\quad[\mathrm{Mo}\{\equiv \mathrm{C}-$ $\left.\left.\mathrm{C}(=\mathrm{S}) \mathrm{NMe}_{2}\right\}(\mathrm{CO})_{2}\left(\mathrm{Tp}^{*}\right)\right](7: \mathrm{Mo}-\mathrm{C}=1.808(4) \AA)$ provide the most germane comparisons (Chart 2). These reference compounds also provide benchmarks that suggest the operation of a degree of 
conjugation between the carbyne (Mo2) and thioacyl (Mo1) components of 3 across the $\mathrm{C} 1-\mathrm{C} 2$ bond (1.383(4) $\AA$ ) which is found to be comparable to the $\mathrm{C}-\mathrm{C}$ bonds of $6(1.370(7) \AA)$ and 7 $(1.444(6) \AA)$. This question was also considered in a computational study (Supporting Information) from which the resulting HOMO-6 demonstrates a delocalised orbital with contributions from the atoms Mo1-S1-C1-C2-Mo2. The HOMO itself (Figure 3) comprises an antibonding interaction of $\pi$-symmetry with respect to the Mo-S vector, suggesting that the sulfur will be prone to electrophilic attack, as demonstrated previously for more conventional thioacyl complexes. ${ }^{18}$ A single example of a binuclear ketenylidene complex, Cowie's $\left[\mathrm{RhOs}(\mu-\mathrm{CCO}) \mathrm{H}(\mathrm{CO})_{3}(\mu \text {-dppm })_{2}\right],{ }^{7 \mathrm{q}}$ has the $\mathrm{CCO}$ ligand symmerically bridging between rhodium and osmium and notably, in solution this complex exists in equilibrium with the $\mu$-ketenyl complex $\left[\mathrm{RhOs}(\mu-\mathrm{CHCO})(\mathrm{CO})_{3}(\mu-\mathrm{dppm})_{2}\right]$.

\section{Table 1. Selected ${ }^{13} \mathrm{C}\left\{{ }^{1} \mathrm{H}\right\}$ NMR Data for Complexeds of the Form $\left[\mathrm{Mo}(\equiv \mathrm{CR})(\mathrm{CO})_{2}(\mathrm{~L})\right]$ and $\left[\mathrm{Mo}\left(\eta^{2}-\mathrm{ACR}\right)(\mathrm{CO})_{2}(\mathrm{~L})\right]$} $(A=0, S$, Se; $L=T$ Tp, Tp*)

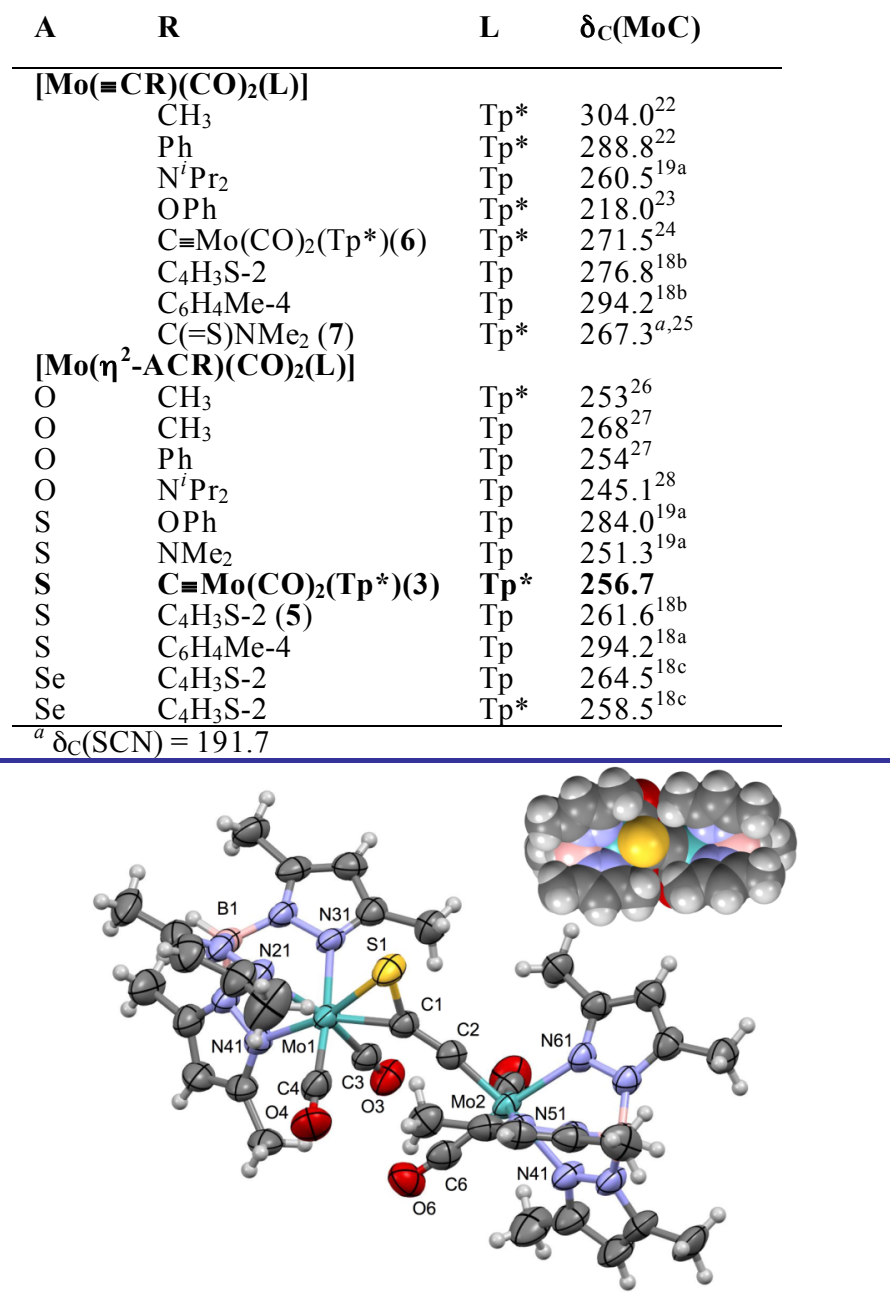

Figure 1: Molecular structure (Table 2) of 3 in a crystal of 3. $\mathrm{CH}_{2} \mathrm{Cl}_{2}(80 \%$ displacement ellipsoids). Inset depicting spacefilling representation viewed along the $\mathrm{Mo}_{2} \mathrm{C}_{2} \mathrm{~S}$ plane.

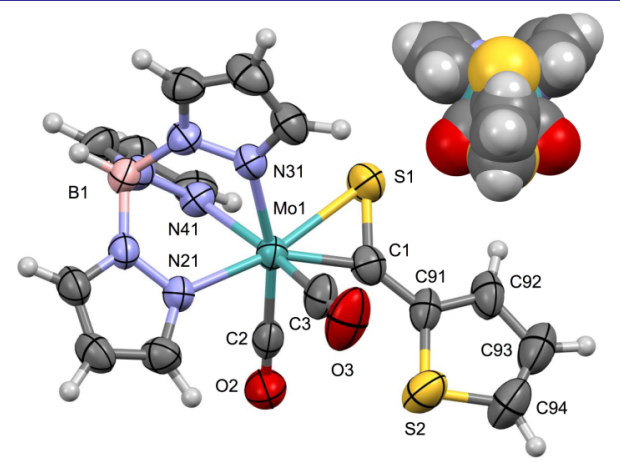

Figure 2: Molecular structure of $\mathbf{5}$ in a crystal $(80 \%$ displacement ellipsoids). Selected bond lengths $(\AA)$ and angles (deg): Mo1-S1 2.5677(8), Mo1-N21 2.192(2), Mo1-N31 2.224(2), Mo1-N41 2.224(2), Mo1-C1 2.000(3), S1-C1 1.679(3), S1-Mo1-C1 40.81(8), Mo1-S1-C1 51.11(9), S1-C1Mo1 88.08(12). Inset indicating space-filling representation and the nestling of the thioacyl group between adjacent pyrazolyl groups.

\begin{tabular}{|c|c|c|c|c|}
\hline \multicolumn{5}{|c|}{$\begin{array}{llllll}\text { Table } & 2 . & \text { A } & \text { Comparison } & \text { of } & \text { the }\end{array}$} \\
\hline \multirow{2}{*}{\multicolumn{5}{|c|}{$\begin{array}{l}\text { Derived (calcd.) Geometric Parameters } \\
\text { Associated with the Metallathiirane Cores } \\
\text { of } 3 \text { and } 5 \text {. }\end{array}$}} \\
\hline & & & & \\
\hline & 5(obs.) & 5(calcd.) & 3(obs.) & 3(calcd.) \\
\hline \multicolumn{5}{|l|}{ Bond Lengths (Å) } \\
\hline Mo1-C1 & $2.00(3)$ & 2.044 & $2.018(3)$ & 2.073 \\
\hline Mo1-S1 & $2.5677(8)$ & 2.621 & $2.5370(7)$ & 2.596 \\
\hline $\mathrm{C} 1-\mathrm{S} 1$ & $1.679(3)$ & 1.690 & $1.700(3)$ & 1.703 \\
\hline $\mathrm{C} 1-\mathrm{C} 2 / \mathrm{C} 91$ & $1.419(9)$ & 1.424 & $1.383(4)$ & 1.381 \\
\hline \multicolumn{5}{|l|}{ Bond Angles (deg.) } \\
\hline C1-Mo1-S1 & $40.81(8)$ & 40.12 & $41.91(8)$ & 40.90 \\
\hline Mo1-C1-S1 & $88.08(12)$ & 88.65 & $85.61(12)$ & 86.27 \\
\hline C1-S1-Mo1 & $51.11(9)$ & 57.22 & $52.48(10)$ & 52.83 \\
\hline $\mathrm{Mo} 1-\mathrm{C} 1-\mathrm{C} 2 / \mathrm{C} 91$ & $147.6(7)$ & 144.01 & $145.9(2)$ & 145.41 \\
\hline
\end{tabular}

Chart 2. Reference Compounds for Bonding in $3 .^{a}$<smiles>C#CC1=C(C#N)S1</smiles>

(3)<smiles></smiles>

(5)

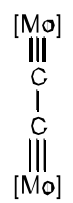

(6)<smiles>C#CC(=S)NC</smiles>

(7)
${ }^{a}$ For 3, 6 and $7[\mathrm{Mo}]=\mathrm{Mo}(\mathrm{CO})_{2}\left(\mathrm{Tp}^{*}\right)$, for $5[\mathrm{Mo}]=$ $\mathrm{Mo}(\mathrm{CO})_{2}(\mathrm{Tp})$. 


\section{Figure 3. The HOMO Calculated for the Optimised} Geometry ${ }^{a}$ of 3.

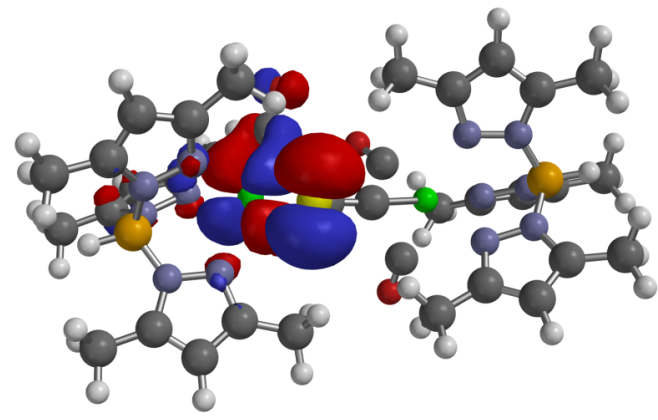

${ }^{a} \mathrm{BP} / \mathrm{TZP}$ level of Theory. See Supporting Information

Given that geometry optimisation at the BP/TZP level of theory effectively reproduced the experimentally determined geometry fo 3, it seemd appropriate to consider situations where one might encounter a thioxoethenylidene bridge displaying different bonding character. The free molecule has triplet diradical character ${ }^{5}$ and so the thioacyl-carbyne bridging mode is perhaps not surprsing when the terminal metal fragments each carry 15 valence electrons (neutral formalism). The question therefore arises as to what effects upon the bridge might attend increasing the number of available valence electrons provided by the metal centres. Notably, the LUMO and LUMO+1 for 3 comprise considerable $\mathrm{C}-\mathrm{C} \pi$-bonding character and Mo-C antibonding character such that successive reduction might be expected to strengthen the $\mathrm{C}-\mathrm{C}$ bond at the expense of $\mathrm{M}-\mathrm{C}$ multiple bonding. This is conceptually achieved by replacing molybdenum first with tungsten $(\mathbf{8})$, then rhenium $(\mathbf{9})$ and finally osmium (10). Tungsten was included so as to afford a series of directly comparable metals with the same principle quantum number. Simple electron counting arguments suggest a single valence bond description for the diosmium complex $\mathbf{1 0}$ involving a conventional alkynyl connection to one osmium and a thiolate coordination to the other (Chart 3 ).

\section{Chart 3. Valence Bond Descriptions for Alternative CCS Coordination Modes. ${ }^{a}$}

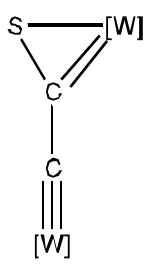

(8)

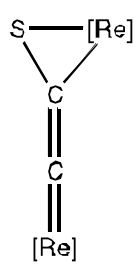

(9a)

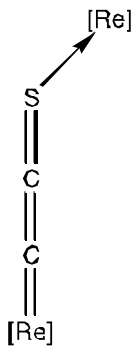

(9b)

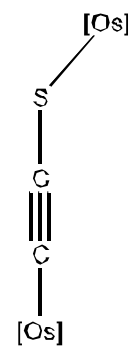

(10)
${ }^{a}[\mathrm{M}]=\mathrm{M}(\mathrm{CO})_{2}\left(\mathrm{Tp}^{*}\right)$.

Alkynylthiolato and alkynylselenolato complexes have been previously described, ${ }^{31}$ though not for osmium. For the dirhenium complex 9, the situation is not as clear-cut in that two possible connectivities are conceivable. In 9a, whilst one rhenium teminus can be considered as a conventional vinylidene linkage, ${ }^{32}$ the other terminus might involve either side-on coordination to the $\mathrm{C}=\mathrm{S}$ double bond $(\mathbf{9 a}),{ }^{32}$ or alternatively simple $\sigma$-coordination by a sulfur lone pair (9b) ${ }^{33}$ It is not clear $a$ priori which would be favoured, given that precedent exists for both types of interaction, $\eta^{2}-C, S$ and $\sigma-S$, with rhenium. ${ }^{32,33}$

Geometry optimisation for $\mathbf{8}$ returns, as expected, a structure that is essentially identical to that for 3 (Table 3, Figure 4a). For the diosmium example 10, the optimisation began with the same geometry as $\mathbf{8}$ and converged on one in which the metal-carbon bond of the metallathiirene cleaved, the OsCCS spine approached linearity (Os-C-C $=176.2, \mathrm{C}-\mathrm{C}-\mathrm{S}=171.9^{\circ}$ ), the $\mathrm{CC}$ bond contracted $(1.236 \AA)$ and the remaining Os- $\mathrm{C}$ bond elongated to a value $(2.037 \AA)$ within the range typical of octahedral osmiumalkynyls $(1.977-2.108 \AA$; average $=2.03 \AA)$. These are all consistent with the alkynylthiolate depiction in Chart 4 .

Table 3. Geometric Parameters Associated with the M'C'CSM Cores of $8(M=W), 9 a(M=R e)$ and $10(M=O s)$.

\begin{tabular}{|c|c|c|c|}
\hline \multirow{2}{*}{\multicolumn{4}{|c|}{ Bond Lengths $(\AA ̊)$}} \\
\hline & & & \\
\hline$M^{\prime}-C^{\prime}$ & 1.869 & 1.939 & 2.037 \\
\hline $\mathrm{C}-\mathrm{C}^{\prime}$ & 1.384 & 1.306 & 1.236 \\
\hline $\mathrm{C}-\mathrm{S}$ & 1.724 & 1.698 & 1.693 \\
\hline $\mathrm{S}-\mathrm{M}$ & 2.588 & 2.478 & 2.455 \\
\hline $\mathrm{C}-\mathrm{M}$ & 2.056 & 2.270 & 3.435 \\
\hline \multicolumn{4}{|c|}{ Bond Angles (deg.) } \\
\hline$M^{\prime}-C^{\prime}-C$ & 172.7 & 174.7 & 176.2 \\
\hline $\mathrm{C}^{\prime}-\mathrm{C}-\mathrm{S}$ & 127.6 & 144.5 & 171.9 \\
\hline $\mathrm{C}-\mathrm{S}-\mathrm{M}$ & 52.4 & 62.6 & 110.5 \\
\hline
\end{tabular}

By commencing with the geometry for 7 but replacing tungsten with rhenium, optimisation results in a geometry consistent with the valence bond description 9a, i.e., a vinylidene linkage to one rhenium and a $\eta^{2}-C, S$-thioketene coordination to the other. Structurally characterised mononuclear vinylidene complexes of rhenium are limited to $\left[\mathrm{Re}(=\mathrm{C}=\mathrm{CHPh})(\mathrm{CO})_{2}\left\{\mathrm{Me}\left(\mathrm{CH}_{2} \mathrm{PPh}_{2}\right)_{3}\right\}\right]^{+}$, $\left[\mathrm{Re}(=\mathrm{C}=\mathrm{CHPh})(\mathrm{CO})_{2}\left(\eta-\mathrm{C}_{5} \mathrm{H}_{5}\right)\right],{ }^{32 \mathrm{~b}} \quad\left[\mathrm{Ru}\left(=\mathrm{C}=\mathrm{CHC}_{10} \mathrm{H}_{7}\right)(\mathrm{NO})-\right.$ $\left.\left(\mathrm{PPh}_{3}\right)\left(\eta-\mathrm{C}_{5} \mathrm{H}_{5}\right)\right]^{+},{ }^{32 \mathrm{c}}$ and $\left[\mathrm{Re}(=\mathrm{C}=\mathrm{CHPh}) \mathrm{Cl}(\text { dppe })_{2}\right],{ }^{32 \mathrm{~d}}$ all of which have essentially linear $\mathrm{Re}=\mathrm{C}=\mathrm{C}$ spines with short $\mathrm{Re}=\mathrm{C}$ and $\mathrm{C}=\mathrm{C}$ bond lengths spanning the ranges $1.839-2.046$ and $1.289-1.388$ Å, respectively.

Structural data available for side on coordination of C-S multiple bonds to rhenium are less directly comparable, being limited to thioaldehyde complexes $\left[\mathrm{Re}\left(\eta^{2}-\mathrm{SCHR}\right)(\mathrm{NO})\left(\mathrm{PPh}_{3}\right)\left(\eta-\mathrm{C}_{5} \mathrm{H}_{5}\right)\right]^{+}(\mathrm{R}=$ $\left.\mathrm{H}^{33 \mathrm{a}} \mathrm{Ph}^{33 \mathrm{~b}}\right)$ and $\left[\mathrm{Re}\left(\eta^{2}-\mathrm{SCHC}_{6} \mathrm{H}_{4} \mathrm{OMe}-4\right)\left(\mathrm{PPhMeC}_{9} \mathrm{H}_{5} \mathrm{NMe}\right)(\eta-\right.$ $\left.\left.\mathrm{C}_{5} \mathrm{H}_{5}\right)\right]^{+}{ }^{33 \mathrm{c}}$ which involve 4-coordinate carbon and $\mathrm{C}-\mathrm{S}$ bonds in the range $1.694-1.731 \AA$ or the complex $\left[\operatorname{Re}\left(\eta^{2}\right.\right.$ $\left.\left.\mathrm{SCNEt}_{2}\right)\left(\mathrm{S}_{2} \mathrm{CNEt}_{2}\right)_{2}\left(\mathrm{PPh}_{3}\right)\right]^{+}$, ${ }^{33 \mathrm{~d}}$ which has a dihapto (3-electron) thiocarbamoyl ligand $(\mathrm{C}-\mathrm{S}=1.606 \AA)$ with associated Re-C multiple bond 'metallathiirene' character $(\mathrm{Re}-\mathrm{C}=2.099 \AA)$. Nevertheless, it is clear that a degree of $\mathrm{C}-\mathrm{S}$ multiple bond character remains in 9a consistent with a Dewar-Chatt-Duncanson description of thioketene coordination.

Whilst frequency calculations were routinely performed to confirm that optimized structures for $\mathbf{3 ,}, \mathbf{8}, \mathbf{9 a}$ and $\mathbf{1 0}$ were minima or saddle points, closer inspection of the infrared data allowed the identification of a mode in each case that could be assigned primarily to the stretching of the $\mathrm{C}-\mathrm{C}$ bond of the $\mathrm{CCS}$ bridge. Consistent with the the valence bond descriptions in Figure 4, the (unscaled) frequency of this absorption increased from those of $8\left(1326,1345 \mathrm{~cm}^{-1}\right)$ to $1682 \mathrm{~cm}^{-1}$ 
for 9a and finally to $2038 \mathrm{~cm}^{-1}$ for $\mathbf{1 0}$, a progression that reflects a sequential increase in $\mathrm{CC}$ bond order, with those for $\mathbf{9 a}$ and $\mathbf{1 0}$ appearing regions typical of vinylidene and alkynyl IR chromophores.

Figure 4. Optimised Geometries for the Complexes $\left[\mathrm{M}_{2}(\mu\right.$ CCS)(CO) $\left.{ }_{4}\left(\mathrm{Tp}^{*}\right)_{2}\right]$ (a) $\mathrm{M}=\mathrm{W}$ (8); (b) $\mathrm{M}=\operatorname{Re}$ (9a); (c) $\mathrm{M}=$ Os (10) (pyrazolylborate ligands simplified for clarity).

(a)

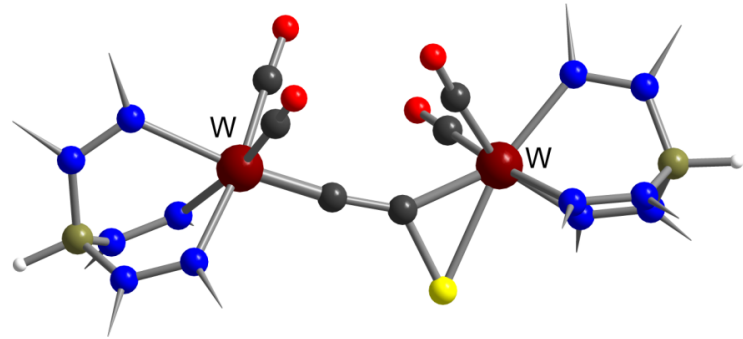

(b)

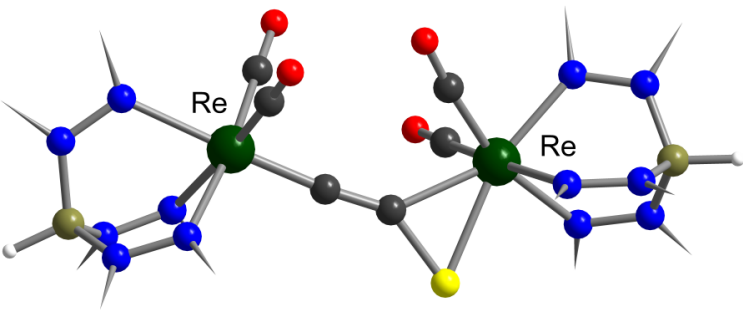

(c)

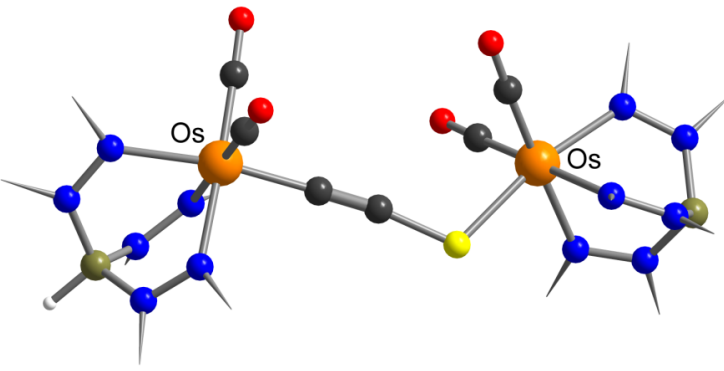

Finally, given the presumption that 3 forms via the intermediacy of a bis(alkylidynyl) thioether $\mathrm{S}\left\{\mathrm{C} \equiv \mathrm{Mo}(\mathrm{CO})_{2}\left(\mathrm{Tp}^{*}\right)\right\}_{2}$ (11), the question of the viability of such a species arises. Geometry optimisation for this proposed intermediate (Figure 5) followed by thermdynamic evaluation suggests that in the gas phase 11 lies some $78.6 \mathrm{~kJ} \mathrm{~mol}^{-1}$ higher in energy than 3. Although a frequency calculation indicates that the geometry is a true local minima with no imaginary frequencies (i.e., the $\mathrm{C}-\mathrm{S}-\mathrm{C}$ bending mode is real), it is of interest to note the unusual deformation from linearity of the $\mathrm{Mo} \equiv \mathrm{C}-\mathrm{S}$ angles $\left(163.8,165.8^{\circ}\right)$ that brings the two carbyne carbons closer than expected, perhaps pointing towards incipient $\mathrm{C} \cdots \mathrm{C}$ bond formation en route to 3 . A concerted process with minimal reorganisatuion would thus seem entirely plausible. Notably, the HOMO for complex 11 corresponds to a delocalised $\pi$-system that is $\mathrm{MC}$ bonding and $\mathrm{C}-\mathrm{S}$ antibonding in character (Figure 5b).

\section{- EXPERIMENTAL}

General Considerations. All manipulations of air-sensitive compounds were carried out under a dry and oxygen-free nitrogen atmosphere using standard Schlenk, vacuum line and inert atmosphere (argon) drybox techniques with dried and degassed solvents. NMR spectra were recorded at $25^{\circ} \mathrm{C}$ on a Varian Mercury $300\left({ }^{1} \mathrm{H}\right.$ at $\left.300.1 \mathrm{MHz}\right)$, Varian Inova $300\left({ }^{1} \mathrm{H}\right.$ at $299.9 \mathrm{MHz},{ }^{13} \mathrm{C}$ at $75.47 \mathrm{MHz})$ or Bruker Avance $600\left({ }^{1} \mathrm{H}\right.$ at $600.0 \mathrm{MHz},{ }^{13} \mathrm{C}$ at 150.9 $\mathrm{MHz})$ spectrometers. Chemical shifts $(\delta)$ are reported in ppm and referenced to the solvent peak $\left({ }^{1} \mathrm{H},{ }^{13} \mathrm{C}\right)$ with coupling constants given in $\mathrm{Hz}$. Infrared spectra were obtained from solution and in the solid state (Nujol) using a Perkin-Elmer Spectrum One FT-IR spectrometer. Elemental microanalytical data were obtained from the ANU Research School of Chemistry microanalytical service. Electrospray ionisation mass spectrometry (ESI-MS) was performed by the ANU Research School of Chemistry mass spectrometry service with acetonitrile as the matrix. Crystallographic data were collected with Nonius Kappa CCD (5) or Agilent Supernova (3) diffractometers. The compounds $\left[\mathrm{Mo}(\equiv \mathrm{CBr})(\mathrm{CO})_{2}\left(\mathrm{Tp}^{*}\right)\right]{ }^{11 \mathrm{~b}}\left[\mathrm{Fe}_{2}\left(\mu-\mathrm{S}_{2}\right)(\mathrm{CO})_{6}\right]^{16}$ and $\left[\mathrm{Mo}\left(\equiv \mathrm{CC}_{4} \mathrm{H}_{3} \mathrm{~S}-\right.\right.$ $\left.2)(\mathrm{CO})_{2}(\mathrm{Tp})\right]^{18 \mathrm{~b}}$ have been described previously. All other reagents were obtained from commercial sources. Cryostatic chromatography was performed under nitrogen using jacketed columns loaded with degassed silica gel, which were cooled by an alcohol recirculating cryostat $\left(-20^{\circ} \mathrm{C}\right)$. Pet. spirit refers to that fraction with bp $60-80^{\circ} \mathrm{C}$. Reaction progress was typically monitored by in situ solution IR spectroscopy and thin layer chromatography (silica gel).

Figure 5. Optimised Geometry for the Hypothetical Complex S\{CMo(CO) $\left.2\left(\mathrm{Tp}^{*}\right)\right\}_{2}$ (11) (a) (pyrazolylborate ligands simplified for clarity). (b) HOMO displaying $\mathrm{M} \equiv \mathrm{C}$ bonding and $\mathrm{C}-\mathrm{S}$ antibonding character

(a)

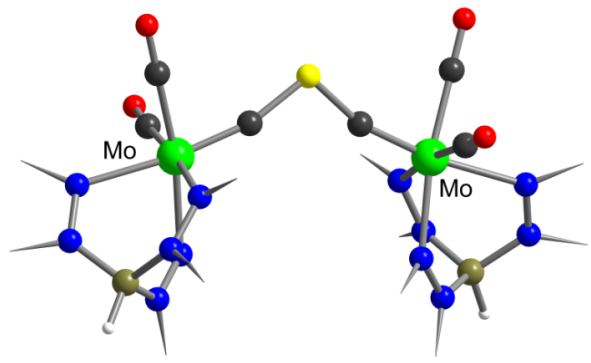

(b)

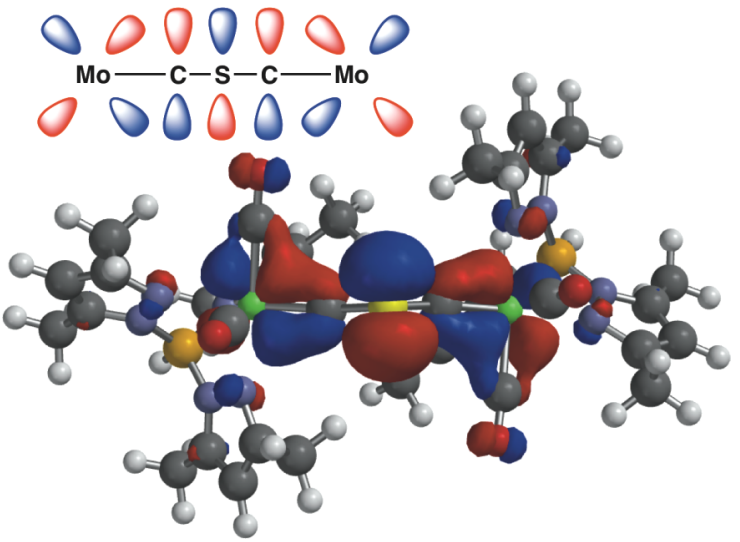

Computational details. Unless otherwise indicated, the DFT calculations reported here were performed using the ADF2009.01 and ADF2010.01 versions of the Amsterdam Density Functional (ADF) program..$^{35,36}$ The calculations employed all-electron valence 
triple- $\zeta$ plus polarization (TZP) Slater orbital basis sets for all atoms and included a correction for scalar relativistic effects through the zeroth-order regular approximation (ZORA) treatment. ${ }^{37}$ Geometry optimizations were performed using the Becke-Perdew (BP) exchange-correlation (XC) functional. ${ }^{38,39}$ Comprehensive efforts were made to obtain the lowest-energy minimum for each compound. The optimized geometries at the BP/TZP level of theory effectively reproduced the experimentally derived geometries for the compounds $\left[\mathrm{Mo}(\equiv \mathrm{CBr})(\mathrm{CO})_{2}\left(\mathrm{Tp}^{*}\right)\right]$ and $\left[\mathrm{Fe}_{2}\left(\mu-\mathrm{S}_{2}\right)(\mathrm{CO})_{6}\right]$ and this level of theory was therefore deemed appropriate. Simplifications for the atom-rich Tp* ligand (such as by Tp, $\eta-\mathrm{C}_{5} \mathrm{H}_{5}$ or $\eta-\mathrm{C}_{5} \mathrm{Me}_{5}$ ) were dismissed in favour of accurately representing the important role that the ligand bulk plays in regard to ligand stabilisation with the central metal atom. The results thus obtained for the unrestricted gas-phase molecules were found to accurately reproduce the crystal structure data.

Synthesis of $\left[\mathbf{M o}_{2}\left(\mu-\mathbf{C}_{2} \mathbf{S}\right)(\mathbf{C O})_{4}(\mathbf{T p} *)_{2}\right]$ (3). Method 1: The complex $\left[\mathrm{Fe}_{2}\left(\mu-\mathrm{S}_{2}\right)(\mathrm{CO})_{6}\right](0.26 \mathrm{~g}, 0.76 \mathrm{mmol})$ was dissolved THF $(10 \mathrm{~mL})$ and cooled to $-78^{\circ} \mathrm{C}$ (dry ice / acetone) and then treated with a solution of $\mathrm{Li}_{[}\left[\mathrm{Et}_{3} \mathrm{BH}\right]\left(1.50 \mathrm{~mL}, 1.50 \mathrm{mmol}, 1.0 \mathrm{molL}^{-1}\right.$ in THF). After stirring for 15 mins, two equivalents of $\left[\mathrm{Mo}(\equiv \mathrm{CBr})(\mathrm{CO})_{2}\left(\mathrm{Tp}^{*}\right)\right](2: 0.81 \mathrm{~g}, 1.5 \mathrm{mmol})$ were added to the dark red solution and stirring continued at $-78^{\circ} \mathrm{C}$ for $3 \mathrm{hrs}$, then allowed to warm to room temeprature and freed of volatiles. The residue was chromatographed on silica gel with a cooling water jacket using a 1:4 $\mathrm{CH}_{2} \mathrm{Cl}_{2}$ /pet spirit mixture as eluent, to provide four separate colored bands. The largest (green) fraction (second fraction) was collected and freed of volatiles and then redissolved in a minimum of $\mathrm{CH}_{2} \mathrm{Cl}_{2}$ and chromatographed on silica gel using a 1:4 $\mathrm{CH}_{2} \mathrm{Cl}_{2} /$ pet spirit mixture as eluent to provide inter alia grey and emerald green bands. The latter was collected, freed of volatiles and crystallised from a mixture of dichloromethane and methanol (1:4, $\left.20{ }^{\circ} \mathrm{C}\right)$. Yield $0.046 \mathrm{~g}(0.048 \mathrm{mmol}, 6.4 \%)$. Method 2 (preferred): Elemental sulfur $(0.014 \mathrm{~g}, 0.44 \mathrm{mg}$.atom $)$ was dissolved in THF $(\sim 20 \mathrm{~mL})$ and treated with a solution of $\mathrm{Li}\left[\mathrm{Et}_{3} \mathrm{BH}\right](0.88 \mathrm{~mL}, 0.88$ mmol, $1.0 \mathrm{molL}^{-1}$ in THF). After stirring for $15 \mathrm{mins}$, $\left[\mathrm{Mo}(\equiv \mathrm{CBr})(\mathrm{CO})_{2}\left(\mathrm{Tp}^{*}\right)\right](2: 0.402 \mathrm{~g}, 0.740 \mathrm{mmol})$ was added to the light yellow solution and stirring continued for seven days. The progress of the reaction was monitored using tlc (silica gel, $\mathrm{CH}_{2} \mathrm{Cl}_{2}$ :hexane $1: 1$ ) to observe the formation of a green compound (the initially formed $\mathrm{Li}\left[\mathrm{Mo}(\mathrm{CS})(\mathrm{CO})_{2}\left(\mathrm{Tp}^{*}\right)\right]$ does not elute with this solvent combination). The mixture was freed of volatiles and cryostatically chromatographed $\left(-20^{\circ} \mathrm{C}\right.$, silica gel) eluting with a 1:4 $\mathrm{CH}_{2} \mathrm{Cl}_{2}$ pet spirit mixture to provide a single emerald green band which was collected, freed of volatiles and crystallised as above. Yield $0.098 \mathrm{~g}(0.103 \mathrm{mmol}, 28 \%)$. IR $\left(\mathrm{CH}_{2} \mathrm{Cl}_{2}\right): 2014,1973$, $1924,1890 \mathrm{~cm}^{-1}\left(v_{\mathrm{CO}}\right) 1545$ ( $\mathrm{BN}_{6} \mathrm{Mo}$ cage breathing). (See Figure S4, Supporting Information for observed and calculated spectra). IR (Nujol): 2540, $2525\left(v_{\mathrm{BH}}\right), 2007,1966,1941,1926,1895\left(v_{\mathrm{CO}}\right) \mathrm{cm}^{-}$ ${ }^{1}$. $\mathrm{NMR}\left(\mathrm{CDCl}_{3}, 298 \mathrm{~K}\right){ }^{1} \mathrm{H}: \delta_{\mathrm{H}}=2.49,2.48,2.40,2.38,2.25(\mathrm{~s} \mathrm{x} \mathrm{5,}$ $\mathrm{pzCH}_{3}$, not all resonances resolved), 5.85, 5.83, 5.82, 5.77 (s x 4, 1 $\left.\mathrm{H} \mathrm{x} \mathrm{4}, \mathrm{C}_{3} \mathrm{HN}_{2}\right) .{ }^{13} \mathrm{C}\left\{{ }^{1} \mathrm{H}\right\}: \delta_{\mathrm{C}}=270.7(\mathrm{Mo} \equiv \mathrm{C}), 256.7(\mathrm{C}=\mathrm{S}), 233.4$, 230.7, 229.9(2C) (MoCO), 152.0, 151.3, 145.4, 145.3, 144.6, 144.3, $107.5, \quad 107.2, \quad 106.8, \quad 106.5 \quad\left(\mathrm{C}_{3} \mathrm{HN}_{2}\right), 16.45(2 \mathrm{C}), 15.54(1 \mathrm{C})$, 15.04(1C), 14.54(2C), 14.34(1C), 13.35(1C) 12.97(2C), 12.89(2C, $\mathrm{pzCH}_{3}$ x 8). ESI-MS (positive ion, $\mathrm{MeCN}$ ): $\mathrm{m} / z=950.2[\mathrm{M}]^{+}, 541.2$ $\left[\mathrm{Mo}_{2}(\mu-\mathrm{CC})(\mathrm{CO})\left(\mathrm{Tp}^{*}\right)\right]^{+}$. Accurate Mass: Found $955.1736[\mathrm{M}]^{+}$, Calcd. for $\mathrm{C}_{36} \mathrm{H}_{44}{ }^{11} \mathrm{~B}_{2}{ }^{98} \mathrm{Mo}_{2} \mathrm{~N}_{12} \mathrm{O}_{4} \mathrm{~S}$ : 955.1730. Anal. Found: $\mathrm{C} 43.80$, $\mathrm{N} 11.83, \mathrm{H}$ 6.51\%. Calcd. for $\mathrm{C}_{36} \mathrm{H}_{44} \mathrm{~B}_{2} \mathrm{Mo}_{2} \mathrm{~N}_{12} \mathrm{O}_{4} \mathrm{~S}_{2} \mathrm{CH}_{2} \mathrm{Cl}_{2}: \mathrm{C}$, $42.76 ; \quad \mathrm{N}, \quad 16.17 ; \quad \mathrm{H}, \quad 4.46 \%{ }^{40}$ Crystal data:
$\mathrm{C}_{36} \mathrm{H}_{44} \mathrm{~B}_{2} \mathrm{Mo}_{2} \mathrm{~N}_{12} \mathrm{O}_{4} \mathrm{~S} . \mathrm{CH}_{2} \mathrm{Cl}_{2}, M_{\mathrm{r}}=1039.32, \mathrm{~T}=150(2) \mathrm{K}$, triclinic, space group $P-1$ (No.2), $a=13.7686(6), b=14.0695(5), c=$ 14.3983(6) $\AA, \alpha=98.002(2), \beta=114.364(2), \gamma=113.651(2)^{\circ}, V=$ 2166.7(2) $\AA^{3}, Z=2, D_{\text {calcd }}=1.367 \mathrm{Mg} \mathrm{m}^{-3}, \mu(\mathrm{Cu} \mathrm{K \alpha}) 5.81 \mathrm{~mm}^{-1}$, dark green lath, $0.03 \times 0.10 \times 0.20 \mathrm{~mm}, 15,595$ measured reflections with $2 \theta_{\max }=144.6^{\circ}, 9,930$ independent reflections, 9,887 adsorption-corrected data used in $F^{2}$ refinement, 541 parameters, no restraints, $R_{1}=0.037, \mathrm{w} R_{2}=0.096$ for 8,958 reflections with $I>$ $2 \sigma(I)$.

Structural analysis of $\left[\mathrm{Mo}\left(\eta^{2}-\mathrm{SCC}_{4} \mathrm{H}_{3} \mathrm{~S}-2\right)(\mathrm{CO})_{2}(\mathrm{Tp})\right]$ (5). The complex $\left[\mathrm{Mo}\left(\eta^{2}-\mathrm{SCC}_{4} \mathrm{H}_{3} \mathrm{~S}-2\right)(\mathrm{CO})_{2}(\mathrm{Tp})\right]$ (5) was prepared as described previously. ${ }^{18 \mathrm{~b}}$ Crystals of the solvate $\mathbf{5} . \mathrm{CH}_{2} \mathrm{Cl}_{2}$ were obtained by slow diffusion of hexane into a dichloromethane solution of 5. Crystal Data: $\mathrm{C}_{16} \mathrm{H}_{13} \mathrm{BMoN}_{6} \mathrm{O}_{2} \mathrm{~S} . \mathrm{CH}_{2} \mathrm{Cl}_{2}, M_{\mathrm{r}}=577.13$, $\mathrm{T}=200(2) \mathrm{K}$, monoclining, space group $P 2_{1} / \mathrm{n}, a=13.5866(2), b=$ 8.37410(10), $c=21.0109(3) \AA, \beta=107.1596(6){ }^{\circ}, V=2284.12(5)$ $\AA^{3}, Z=4, D_{\text {calcd }}=1.678 \mathrm{Mg} \mathrm{m}^{-3}, \mu(\mathrm{Mo} \mathrm{K} \alpha) 1.018 \mathrm{~mm}^{-1}$, black block, $0.12 \times 0.15 \times 0.37 \mathrm{~mm}, 32,944$ measured reflections with $2 \theta_{\max }=54.9^{\circ}, 5,233$ independent, adsorption-corrected reflections used in $F^{2}$ refinement, 296 parameters, 18 restraints, $R_{1}=0.0237$, $\mathrm{w} R_{2}=0.0254$ for 3,110 reflections with $I>3 \sigma(I)$.

\section{- CONCLUSIONS}

In summary, we have with the isolation of $\mathbf{3}$ shown that thioxoethenylidene is a viable bridging ligand in a mode in which it provides 6 valence electrons to the two metal centres. Though yet to be established, we have also suggested that alternative binding modes might be available in which the CCS ligand provides in total 4 or 2 valence electrons, depending on the effective atomic number requirements of the metal termini. It remains to be seen whether such complexes can be synthesised or indeed whether a mononuclear terminal coordination mode, $\mathrm{L}_{\mathrm{n}} \mathrm{M}=\mathrm{C}=\mathrm{C}=\mathrm{S}$, is attainable, by analogy with Hillhouse's putative complex $\left[\mathrm{WCl}_{2}(=\mathrm{C}=\mathrm{C}=\mathrm{O})(\mathrm{CO})\left(\mathrm{PMePh}_{2}\right)_{2}\right] .^{8}$

\section{- AUTHOR INFORMATION Corresponding Author}

*Email: a.hill@anu.edu.au (A.F.H)

\section{Notes}

The authors declare no competing financial interest.

\section{- ACKNOWLEDGEMENTS}

This work was supported by the Australian Research Council (DP130102598 and DP110101611).

\section{REFERENCES}

(1) Baird, M. C.; Wilkinson, G. Chem. Commun. 1966, 267.

(2) (a) Broadhurst, P. V. Polyhedron 1985, 4, 1801. (b) Petz, W. Coord. Chem. Rev. 2008, 252, 1689.

(3) Penzias, A. A.; Jefferts, K. B.; Wilson, R. W.; Liszt, H. S.; Solomon, P. M. Astrophys. J. 1972, 178, L35.

(4) Steudel, R. Z. Naturforsch. 1966, 26B, 1106.

(5) (a) Saito, S.; Kawaguchi, K.; Yamamoto, S.; Ohishi, M.; Suzuki, H.; Kaifu, N.; Astrophys. J. 1987, 317, L115. (b) Suzuki, H.; Kaifu, N.; Miyaji, T.; Morimoto, M.; Ohishi, M.; Saito, S.; Astrophys. J. 1984, 282, 197. (c) Yamamoto, S.; Saito, S.; Kawaguchi, K.; Chikada, Y.; Suzuki, H.; Kaifu, N.; Ichikawa, S.; Ohishi, M. Astrophys. J. 1990, 361,318 . 
(6) Maier, G.; Reisenauer, H.-P.; Ruppel, R. Eur. J. Org. Chem. 2004 4197

(7) (a) Norton, D. M.; Shriver, D. F. Inorg. Chem. 2000, 39, 5118. (b) Eveland, R. W.; Raymond, C. C.; Albrecht-Schmitt, T. E.; Shriver, D. F. Inorg. Chem. 1999, 38, 1282. (c) Xiao, F.-S.; Ichikawa, M. J. Mol. Cat. 1996, 113, 427. (d) Wong, W.-Y.; Wong, W.-T. J. Chem. Soc., Dalton Trans. 1995, 2735. (e) Thoene, C.; Vahrenkamp, H. J. Organomet. Chem. 1995, 485, 185. (f) Norton, D. M.; Stern, C. L.; Shriver, D. F. Inorg. Chem. 1994, 33, 2701. (g) Johnston, D. H.; Stern, C. L.; Shriver, D. F. Inorg. Chim. Acta 1993, 213, 83. (h) Heineke, D.; Bohle, D. S.; Vahrenkamp, H. Chem. Ber. 1993, 126, 355. (i) Jensen, M. P.; Shriver, D. F. J. Mol. Cat. 1992, 74, 73. (j) Jensen, M. P.; Phillips, D. A.; Sabat, M.; Shriver, D. F. Organometallics 1992, 11, 1859. (k) Jensen, M. P.; Henderson, W.; Johnston, D. H.; Sabat, M.; Shriver, D. F. J. Organomet. Chem. 1990, 394, 121. (1) D'Agostino, M. F.; McGlinchey, M. J. Polyhedron 1988, 7, 807. (m) Went, M. J.; Sailor, M. J.; Bogdan, P. L.; Brock, Carolyn P.; Shriver, D. F. J. Am. Chem. Soc. 1987, 109, 6023. (n) Kolis, J. W.; Holt, E. M.; Shriver, D. F. J. Am. Chem. Soc. 1983, 105, 7307. (o) Sievert, A. C.; Strickland, D. S.; Shapley, J. R.; Steinmetz, G. R.; Geoffroy, G. L. Organometallics 1982, 1, 214. (p) Sallor, M. J.; Shriver, D. F. Organometallics 1985, 4, 1476. (q) Wells, K. D.; McDonald, R.; Ferguson, M. J.; Cowie, M. Inorg. Chem. 2011, 50,3523 .

(8) (a) List, A. K.; Hillhouse, G. L.; Rheingold, A. L. J. Am. Chem. Soc. 1988, 110, 4855. (b) List, A. K.; Hillhouse, G. L.; Rheingold, A. L. Organometallics 1989, 8, 2010.

(9) (a) Hill, A. F.; Malget, J. M. J. Chem. Soc., Chem. Commun. 1996 1177. (b) Hill, A. F.; Malget, J. M.; White, A. J. P.; Williams, D. J. Organometallics 1998, 37, 598. (c) Baxter, I.; Hill, A. F.; Malget, J. M. J. Chem. Soc., Chem. Commun. 1997, 2049.

(10) (a) Cade, I. A.; Hill, A. F.; McQueen, C. M. A. Organometallics 2009, 28, 6639. (b) Hill, A. F.; Colebatch, A. L.; Cordiner, R. L.; Dewhurst, R. D.; McQueen, C. A. M.; Nguyen, K. T. H. D.; Shang, R.; Willis, A. C. Comm. Inorg. Chem. 2010, 31, 121. (c) Caldwell, L. M.; Cordiner, R. L.; Hill, A. F.; Wagler, J. Organometallics 2010, 29 , 1526. (d) Caldwell, L. M.; Hill, A. F.; Wagler, J.; Willis, A. C. Dalton Trans. 2008, 3538. (e) Caldwell, L. M.; Hill, A. F.; Rae, A. D.; Willis, A. C. Organometallics 2008, 27, 341. (f) Hill, A. F.; McQueen, C. M. A. Organometallics 2012, 31, 2482.

(11) (a) Lalor, F. J.; Desmond, T. J.; Cotter, G. M.; Shanahan, C. A.; Ferguson, G.; Parvez, M.; Ruhl, B. J. Chem. Soc., Dalton Trans. 1995, 1709. (b) Cordiner, R. L.; Hill, A. F.; Wagler, J. Organometallics 2008, 27, 5177.

(12) (a) Quick, M. H.; Angelici, R. J. Inorg. Chem. 1982, 21, 1674. (b) Quick, M. H.; Angelici, R. J. Inorg. Chem. 1981, 20, 1123. (c) Wnuk, T. A.; Angelici, R. J. Inorg. Chem. 1977, 16, 1173. (d) Dombek, B. D.; Angelici, R. J. J. Am. Chem. Soc. 1974, 96, 7568. (e) Angelici, R. J. Acc. Chem. Res. 1972, 18, 335 .

(13)Kim, H. P.; Kim, S.; Jacobson, R. A.; Angelici, R. J. J. Am. Chem. Soc. 1986, 108, 5154.

(14) Doyle, R. A.; Daniels, L. M.; Angelici, R. J.; Stone, F. G. A. J. Am Chem. Soc. 1989, 111, 4995.

(15) Hieber, W.; Gruber, J. Z. Anorg. Allg. Chem. 1958, 296, 91. (b) Hieber, W.; Beck, W. Z. Anorg. Allg. Chem. 1960, 305, 265. (c)Wei, C. H.; Dahl, L. F. Inorg. Chem. 1965, 4, 1.

(16) Seyferth, D.; Womack, G. B. Organometallics 1986, 5, 2360.

(17) Caldwell, L. M. Adv. Organomet. Chem. 2008, 56, 1 .

(18) (a) Cook, D. J.; Hill, A. F. Chem. Commun. 1997, 955. (b) Cook, D. J.; Hill, A. F. Organometallics 2003, 22, 3502. (c) Caldwell, L. M.; Hill, A. F.; Willis, A. Chem. Commun. 2005, 2615.

(19) (a) Anderson, S.; Cook, D. J.; Hill, A. F. Organometallics 2001, 20, 2468. (b) Desmond, T.; Lalor, F. J.; O'Sullivan, B.; Ferguson, G. $J$. Organomet. Chem. 1990, 381, C33. (c) Ogric, C.; Lehotkay, T.; Wurst, K.; Jaitner, P.; Kreiß1, F. R. J. Organomet. Chem. 1997, 541, 71. (d) Luo, X.-L.; Kubas, G. J.; Burns, C. J.; Butcher, R. J. Organometallics 1995, 14, 3370. (e) Herrick, R. S.; NieterBurgmayer, S. J.; Templeton, J. L. J. Am. Chem. Soc. 1983, 105, 2599. (f) Ricard, L.; Estienne, J.; Weiss, R. Inorg. Chem. 1973, 12, 2182.

(20) (a) Byrne, P. G.; Garcia, M. E.; Jeffery, J. C.; Sherwood, P.; Stone, F. G. A. J. Chem. Soc., Dalton Trans. 1987, 1215. (b) Hill, A. F.; Nasir, B. A.; Stone, F. G. A. Polyhedron 1989, 8, 179. (c) Carriedo, G. A.;
Jeffery, J. C.; Stone, F. G. A. J. Chem. Soc., Dalton Trans. 1984, 1597. (d) Anderson, S.; Hill, A. F.; Nasir, B. A. Organometallics 1995, 14, 2987. (e) Alper, H.; Einstein, F. W. B.; Hartstock, F. W.; Willis, A. C. J. Am. Chem. Soc. 1985, 107, 173. (f) Hulkes, A. G.; Hill, A. F.; Nasir, B. A.; White, A. J. P.; Williams, D. J. Organometallics 2004, 23, 679.

(21) Ellis, D. D.; Farmer, J. M.; Malget, J. M.; Mullica, D. F.; Stone, F. G. A. Organometallics 1998, 17, 5540.

(22) Brower, D. C.; Stoll, M.; Templeton, J. L. Organometallics 1989, 8, 2786.

(23) Jamison, G. M.; White, P. S.; Templeton, J. L. Organometallics 1991, 10, 1954

(24) Colebatch, A. L.; Cordiner, R. L.; Hill, A. F.; Nguyen, K. T. H. D.; Shang, R.; Willis, A. C. Organometallics, 2009, 28, 4394.

(25) Colebatch, A. L.; Hill, A. F.; Shang, R.; Willis, A. C. Organometallics 2010, 29, 6482.

(26) Rusik, C. A.; Collins, M. A.; Gamble, A. S.; Tonker, T. L.; Templeton, J. L. J. Am. Chem. Soc. 1989, 111, 2550.

(27) Curtis, M. D.; Shiu, K.-B.; Butler, W. M. J. Am. Chem. Soc. 1986, $108,1550$.

(28) Anderson, S.; Cook, D. J.; Hill, A. F. Organometallics 1997, 16, 5595.

(29) CCDC. NB - in addition to electronic considerations, Schrock-type carbenes are typically associated with metal centres with lower coordination numbers which also contributes to shorter $\mathrm{M}-\mathrm{C}$ bond lengths.

(30) Angles at carbon for carbyne ligands have been observed to be as small as $163^{\circ}$ and such deformations are generally attributed to crystal packing effects. ${ }^{10 \mathrm{~d}, 17}$

(31) (a) Weigand, W. Z. Naturforsch., B 1991, 46, 1333. (b) Weigand, W.; Robl, C. Chem. Ber. 1993, 126, 1807. (c) Weigand, W.; Weishaupl, M.; Robl, C. Z. Naturforsch., B 1996, 51, 501. (d) Cerrada, E.; Laguna, M.; Lardies, N. Eur. J. Inorg. Chem. 2009, 137. (e) Lardies, N.; Romeo, I.; Cerrada, E.; Laguna, M.; Skabara, P. J. Dalton Trans. 2007, 5329. (f) Delgado, E.; Hernandez, E.; Menacho, M.; Munoz, R. Inorg. Chem. Commun. 2006, 9, 139. (g) Delgado, E.; Donnadieu, B.; Garcia, S.; Zamora, F. J. Organomet. Chem. 2002, 649, 21. (h) Ara, I.; Delgado, E.; Fornies, J.; Hernandez, E.; Lalinde, E.; Mansilla, N.; Moreno, M. T. J. Chem. Soc., Dalton Trans. 1998, 3199. (i) Caldwell, L. M.; Hill, A. F.; Hulkes, A. G.; McQueen, C. M. A.; White, A. F. P.; Williams, D. J. Organometallics 2010, 29, 6350. (j) Bedford, R. B.; Dyson, P. J.; Hill, A. F.; Hulkes, A. G.; Yates, C. J. Organometallics 1998, 17, 4117. (k) Beswick, M. A.; Raithby, P. R.; Steiner, A.; Vallat, J. C.; Verhorevoot, K. L.; Wright, D. S. J. Chem. Soc., Dalton Trans. 1996, 2183. (1) Beswick, M. A.; Harmer, C. N.; Raithby, P. R.; Steiner, A.; Tombul, M.; Wright, D. S. J. Organomet. Chem. 1999, 573, 267. (m) Sunada, Y.; Hayashi, Y.; Kawaguchi, H.; Tatsumi, K. Inorg. Chem. 2001, 40, 7072. (n) Sugiyama, H.; Hayashi, Y.; Kawaguchi, H.; Tatsumi, K. Inorg. Chem. 1998, 37, 6773. (o) Schaefer, S.; Moser, C.; Tirree, J. J.; Nieger, M.; Pietschnig, R. Inorg. Chem. 2005, 44, 2798. (p) Pietschnig, R.; Merz, K.; Schaefer, S. Heteroat. Chem. 2005, 16, 169.

(32) (a) Bianchini, C.; Marchi, A.; Marvelli, L.; Peruzzini, M.; Romerosa, A.; Rossi, R. Organometallics 1996, 15, 3804. (b) Valyaev, D. A.; Semeikin, O. V.; Peterleitner, M. G.; Borisov, Y. A.; Khrustalev, V. N.; Mazhuga, A. M.; Kremer, E. V.; Ustynyuk, N. A. J. Organomet. Chem. 2004, 689, 3837. (c) Senn, D. R.; Wong, A.; Patton, A. T.; Marsi, M.; Strouse, C. E.; Gladysz, J. A. J. Am. Chem. Soc. 1988, 110, 6096. (d) Pombeiro, A. J. L.; Almeida, S. S. P. R.; Silva, M. F. C. G.; Jeffrey, J. C.; Richards, R. L. J. Chem. Soc., Dalton Trans. 1989, 2381

(33) (a) Buhro, W. E.; Etter, M. C.; Georgiou, S.; Gladysz, J. A.; McCormick, F. B. Organometallics 1987, 6, 1150. (b) Schenk, W. A.; Burzlaff, N.; Burzlaff, H. Z. Naturforsch., B. 1994, 49, 1633. (c) Bock, F.; Fischer, F.; Radacki, K.; Schenk, W. A. Eur. J. Inorg.Chem. 2010, 391.

(33)Nock, B.; Maina, T.; Tisato, F.; Raptopoulou, C. P.; Terzis, A.; Chiotellis, E. Inorg. Chem. 2000, 39, 5197.

(34)(a) Bajo, S.; Esteruelas, M.A.; Lopez, A. M.; Oñate, E. Organometallics 2012, 31, 8618. (b) Wen, T. B.; Zhou, Z. Y.; Jia, G. Organometallics 2003, 22, 4947. (c) Buil, M. L.; Esteruelas, M. A.; Garces, K.; Oñate, E. J. Am. Chem. Soc. 2011, 133, 2250. (d) Wong, W.-Y.; Ho, K.-Y.; Ho, S. L Lin, Z. J. Organomet. Chem. 2003, 683, 
341. (e) West, P. J.; Schwich, T.; Cifuentes, M. P.; Humphrey, M. G. J. Organomet. Chem. 2011, 696, 2886. (f) West, P. J.; Cifuentes, M. P.; Schwich, T.; Randles, M. D.; Morrall, J. P.; Kulasekera, E.; Petrie, S.; Stranger, R.; Humphrey, M. G. Inorg. Chem. 2012, 51, 10495. (g) Werner, H.; Flugel, R.; Windmuller, B. Chem. Ber. 1997, 130, 493. (h) Espuelas, J.; Esteruelas, M. A.; Lahoz, F. J.; Oro, L. A.; Valero, C. Organometallics 1993, 12, 663. (i) Esteruelas, M. A.; Lahoz, F. J.; Lopez, A. M.; Oñate, E.; Oro, L. A. Organometallics 1995, 14, 2496.

(35) te Velde, G.; Bickelhaupt, F. M.; van Gisbergen, S. J. A; Guerra, C. F.; Baerends, E. J.; Snijders, T.; Ziegler, J. G. J. Comput. Chem. 2001, 22,931

(36) ADF2010.01; SCM, Theoretical Chemistry, Vrije Universiteit, Amsterdam, The Netherlands; http://www.scm.com.

(37) van Lenthe, E.; Baerends, E. J.; Snijders, J. G. J. Chem. Phys. 1993 99, 4597.

(38) Becke, A. D. Phys. Rev. A 1998, 38, 3098

(39) Perdew, J. P. Phys. Rev. B 1986, 33, 8822.

(40) Although these results are outside the range viewed as establishing analytical purity, they are provided to illustrate the best values obtained to date. For poly(pyrazolyl)borate complexes low nitrogen content is on occasion attributed to the formation of refractory boron nitrides during incomplete combustion. 
$2 \mathrm{~L}_{5} \mathrm{Mo} \equiv \mathrm{C}-\mathrm{Br}$

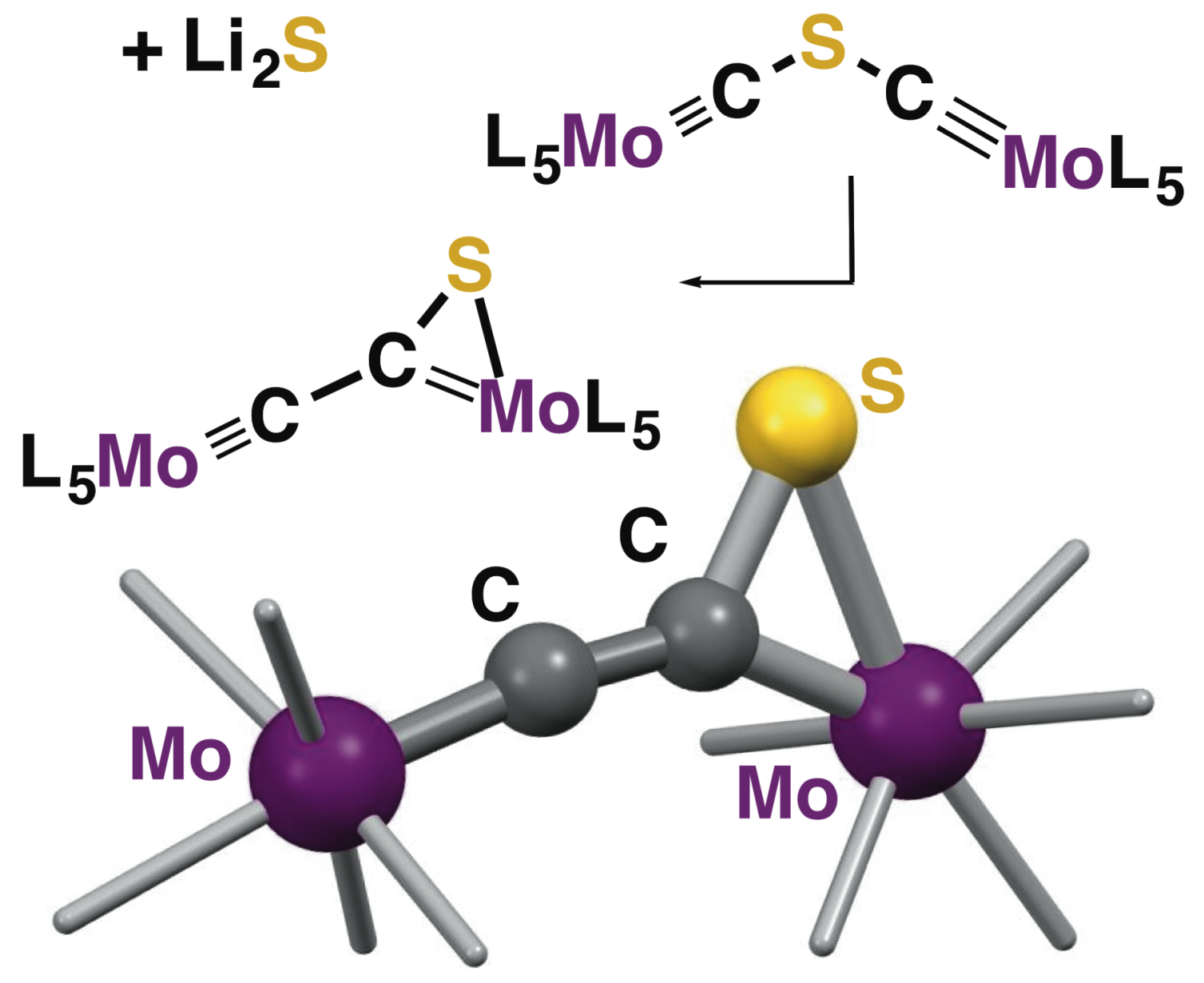

